B. Bourouis, H. Djeghloud, H. Benalla

\title{
AN INNOVATIVE ALGORITHM FOR A HYBRID FC/BATTERY SYSTEM ENERGY MANAGEMENT
}

Purpose. This paper targets to manage the energy of a hybrid fuel-cell (FC)/battery power system using an innovative algorithm. The hybrid FC/Battery power system is based on four stacks PEM FCs and a NiMH battery, boost and buck DC choppers for controlling the FC and the battery input currents respectively and a developed algorithm both for managing the power system energies and for delivering the FC and the battery reference output voltages compulsory for the DC/DC converters control circuits. The study is verified by means of computer simulations using MATLAB/Simulink where several cases of the battery SOC and the power demand levels were taken into account. The results demonstrate a good functioning of the proposed hybrid FC/Battery power system managing algorithm. References 25, tables 4, figures 17.

Key words: hybrid FC/battery system, PEM FC, NiMH battery, boosts and bucks DC/DC converters, innovative management algorithm.

Мета. Стаття спрямована на управління енергією гібридної системи жсивлення від паливного елемента/акумулятора за допомогою інноваційного алгоритму. Гібридна система живлення паливний елемент/акумулятор заснована на чотирьох батареях паливних елементів з протонообмінними мембранами та NіМН акумуляторі, підсилювачах і послаблювачах постійного струму для управління паливним елементом та вхідними струмами батареї відповідно та розробленому алгоритмі як для управління енергісю енергосистеми, так $і$ для подачі на паливний елемент $і$ акумулятор вихідної напруги, обов'язкової для схем управління перетворювачами постійного струму. Дослідження перевірено за допомогою комп'ютерного моделювання з використанням MATLAB/Simulink, де було враховано кілька випадків рівня заряду акумулятора та рівнів споживання енергії. Результати демонструють добре функціонування запропонованого гібридного алгоритму управління системою живлення від паливного елемента/акумулятора. Бібл. 25, табл. 4, рис. 17.

Ключові слова: гібридна система паливний елемент/акумулятор, паливний елемент 3 протонообмінними мембранами, NiMH акумулятор, підсилювачі та перетворювачі постійного струму, інноваційний алгоритм управління.

Introduction. Fuel cell (FC) technology is known as the most cleaned converter of hydrogen into electrical energy which constitutes an advantageous alternative to polluting fossil fuel sources of electrical energy [1-4]. Moreover, FCs are highly efficient, modular and low cost with less weight and volume if compared to conventional power generation sources [5, 6]. Various technologies of FCs are commercialized but the low temperature proton exchange membrane (PEM) fuel cell is the most popular [7, 8].

However the PEMFCs response time is considerable which involves assistance of energy storage equipment to convey the energy to the loads which power demand varies rapidly [7], [9]. The hybridization of FCs is generally performed with batteries or super-capacitors or both of them $[10,11]$.

Particularly, when it is question of a hybrid FC/battery system, an energy management unit is primordial for achieving the optimal performances since both FCs and batteries face many challenges during the operational mode which influences on their lifetime and reliability [12].

Hybrid FC/battery systems can be found in diverse applications including but not limited to portable power generation, power transportation and stationary power generation [13].

In this paper, an innovative algorithm is presented for managing the energy of a hybrid FC/battery power system. The adopted FC is a PEM type whereas the battery is from NiMH technology. The energy management is based on controlling the $\mathrm{FC}$ and the battery input currents through $\mathrm{DC} / \mathrm{DC}$ boost and buck converters. Simulation tests on a resistive load were performed on a wide range of voltages.

System description. The considered system is depicted in Fig. 1. The system contains four stacks fuelcell system, a battery, a unidirectional boost DC/DC converter, a bidirectional boost/buck DC/DC converter, and an energy management algorithm. Further details are reported in the following sections.

Model of the hybrid fuel-cell/battery system. FCs have the benefits of high efficiency since they transform fuel energy directly into electrical energy without any internal combustion. Nevertheless, they are heavy and bulky systems with long start-up and response times [14]. Hybridization of the FC with a battery, which is a peaking power source is an effective way to overcome the FC drawbacks. This is why the hybrid FC/battery system is considered in this contribution. The model of the fuelcell/battery hybrid system is based on fuel cell and battery blocs available in the SimPowerSystem (SPS) library browser of MATLAB/Simulink.

1. Fuel cell model. Fuel cells are electrochemical devices organized in stacks that transform chemical energy from an electrolytic reaction to electrical energy, evacuating heat and water. Nevertheless, FCs remain incapable to supply a regulated DC voltage although they are a spotless source of energy. FCs found their utility in many applications such as power generation and co-generation plants, main power sources in remote locations (spacecrafts, weather station and so on), automotive appliances (cars, buses, motorcycles, bicycles, airplanes, forklifts, submarines and so on), and others (distributed generation, emergency

(C) B. Bourouis, H. Djeghloud, H. Benalla 
power systems, UPS's, notebook computers, small heating systems and so on). Many kinds of FCs exist namely: alkaline (AFC), proton exchanges membrane (PEMFC), phosphoric acid (PAFC), molten carbonates (MCFC), and solid oxides (SOFC) [15]. PEMFCs are the most widespread fuel cells because of their low operating temperature compared to the other kinds $\left(60-100^{\circ} \mathrm{C}\right)[16]$.

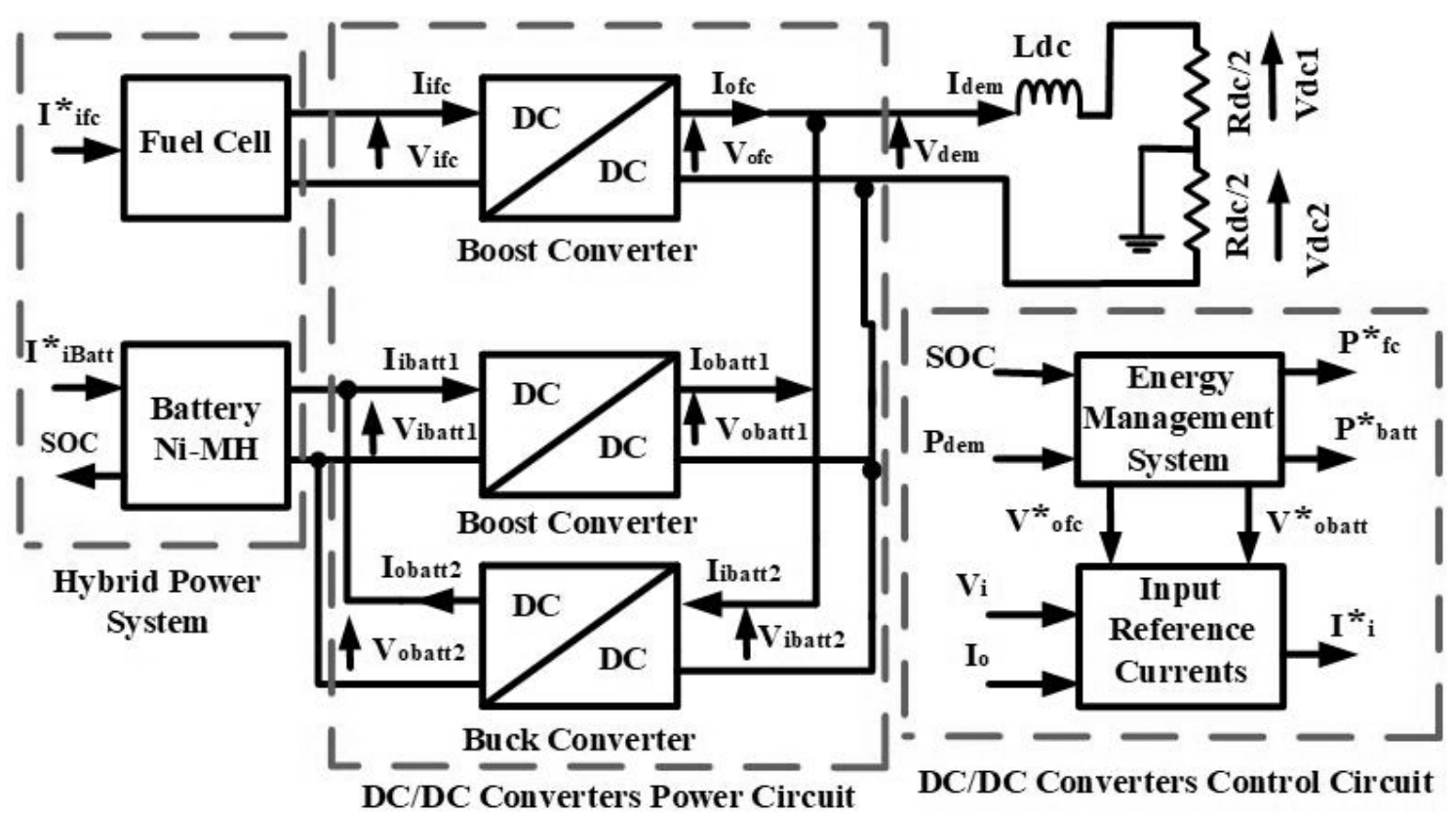

Fig. 1. Description of system

1.1. Modeling of the PEMFC. The SPS FC model is the approach proposed in [17]. The model of the FC stack implemented in SPS is shown in Fig. 2.

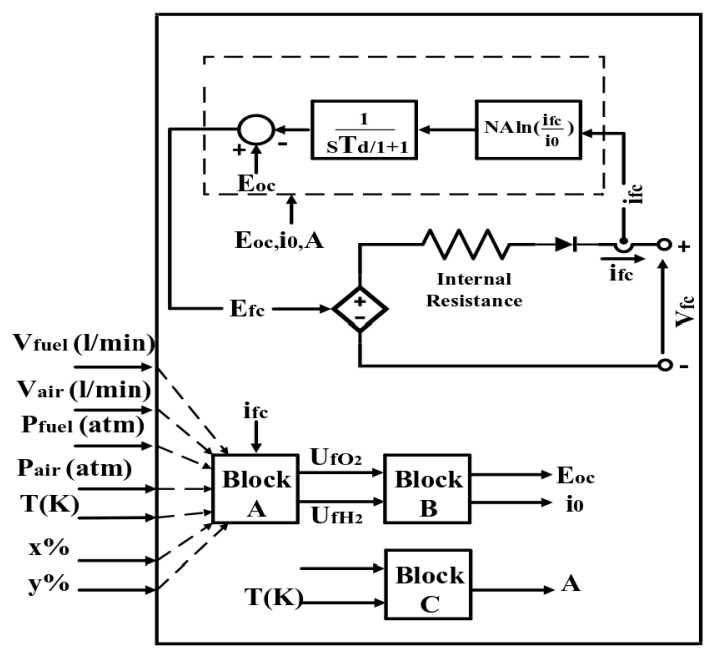

Fig. 2. Fuel cell stack model

- Transient state. This model is selected for this paper and the main equations are as follows [17]. The controlled voltage source $\left(E_{f c}\right)$ is expressed as:

$$
E_{f c}=E_{o c}-N \cdot A \cdot \ln \left(\frac{i_{f c}}{i_{0}}\right) \cdot \frac{1}{\frac{s \cdot T_{d}}{3}+1},
$$

where $E_{o c}$ - open circuit voltage, $\mathrm{V} ; N$ - number of cells; $A$ - Tafel slope, $\mathrm{V} ; i_{0}-$ exchange current, $\mathrm{A} ; T_{d}$ - the response time, $\mathrm{s} ; i_{f c}-$ fuel cell current, A.

The first order transfer function appearing in (1) represents the FC activation losses due to slowness in chemical reactions occurring in the electrodes surfaces.
These losses can be electrically modeled by a parallel $R C$ circuit. Then $T_{d}$ can be taken as 3 times the time constant $\tau=R C$. Thus the FC voltage considering both electrodes and electrolyte losses is determined from (2) :

$$
V_{f_{c}}=E_{f_{c}}-R_{f_{c}} \cdot i_{f_{\mathcal{C}}},
$$

where $R_{f c}$ - internal resistance of the FC, $\Omega ; V_{f c}$ - fuel cell voltage, $\mathrm{V} ; E_{o c}, i_{0}$, A are as follows:

$$
\begin{gathered}
E_{o c}=N_{c} \cdot E_{n} ; \\
i_{0}=\frac{z \cdot F \cdot k\left(P_{H_{2}}+P_{O_{2}}\right)}{R \cdot h} \cdot e^{\frac{-\Delta G}{R \cdot T}} ; \\
A=\frac{R \cdot T}{z \cdot a \cdot F},
\end{gathered}
$$

where $R=8.3145 \mathrm{~J} /(\mathrm{mol} \cdot \mathrm{K}) ; F=96485 \mathrm{~A} \cdot \mathrm{s} / \mathrm{mol} ; \mathrm{z}-$ number of moving electrons $(z=2) ; E_{n}$ - Nernst voltage, $\mathrm{V} ; a$ - charge transfer coefficient; $P_{H_{2}}$ - partial pressure of hydrogen inside the stack, atm; $P_{\mathrm{O}_{2}}$ - partial pressure of oxygen inside the stack, atm; $P_{\mathrm{H}_{2} \mathrm{O}}$ - partial pressure of water vapor, atm; $w$ - percentage of water vapor in the oxidant, $\%$; $k$ - Boltzmann's constant $\left(1.38 \cdot 10^{-23} \mathrm{~J} / \mathrm{K}\right)$; $h$ - Planck's constant $\left(6.626 \cdot 10^{-34} \mathrm{~J} \cdot \mathrm{s}\right) ; \Delta G$ - activation energy barrier, $\mathrm{J}$; $T$ - temperature of operation, $\mathrm{K}$; $K_{c}$ - voltage constant at nominal condition of operation.

$$
E_{n}=\left\{\begin{array}{l}
1.229+(T+298) \cdot \frac{-44.43}{z \cdot F}+\frac{R \cdot T}{z \cdot F} \ln \left(P_{H_{2}} \cdot P_{O_{2}}{ }^{1 / 2}\right) \\
T \leq 100^{\circ} C ; \\
1.229+(T+298) \cdot \frac{-44.43}{z \cdot F}+\frac{R \cdot T}{z \cdot F} \ln \left(\frac{P_{H_{2}} \cdot P_{O_{2}}{ }^{1 / 2}}{P_{H_{2} O}}\right) ; \\
T>100^{\circ} C ;
\end{array}\right.
$$




$$
\begin{gathered}
P_{\mathrm{H}_{2}}=\left(1-U_{f H_{2}}\right) \cdot x \cdot P_{f u e l} ; \\
P_{\mathrm{O}_{2}}=\left(1-U_{f \mathrm{O}_{2}}\right) \cdot y \cdot P_{\text {air }} ; \\
P_{\mathrm{H}_{2} \mathrm{O}}=\left(w+2 \cdot y \cdot U_{f O_{2}}\right) \cdot P_{\text {air }} ; \\
U_{f H_{2}}=\frac{60000 \cdot R \cdot T \cdot N \cdot i_{f c}}{z \cdot F \cdot P_{f u e l} \cdot V_{f u e l} \cdot x} ; \\
U_{f o_{2}}=\frac{60000 \cdot R \cdot T \cdot N \cdot i_{f c}}{2 \cdot z \cdot F \cdot P_{\text {air }} \cdot V_{\text {air }} \cdot y},
\end{gathered}
$$

where $P_{\text {fuel }}$ - absolute supply pressure of fuel, atm; $P_{\text {air }}-$ absolute supply pressure of air, atm; $V_{\text {fuel }}$ - fuel flow rate, $1 / \mathrm{min} ; V_{\text {air }}$ - air flow rate, $1 / \mathrm{min} ; x$ - percentage of hydrogen in the fuel, $\% ; y$-percentage of oxygen in the oxidant, \%.

The air compressor has a delay that results are a lack of oxygen inside the fuel cell. Consequently the utilization of the cell exceeds the nominal values which influence the Nerst voltage. This influence can be expressed as [17]:

$$
E_{n \text { (modified) }}=E_{n}-K_{f c}\left(U_{f O_{2}}-U_{f O_{2} \text { nom }}\right)
$$

where $K_{f c}$ - voltage undershoots constant; $U_{f O_{2 n o m}}-$ nominal oxygen utilization, $\%$.

- Steady state. The modeling of the steady state consists to consider the previous equations with their given values (nominal values) and to suppress the transfer function.

$$
\begin{gathered}
V_{1}=E_{o c}-N \cdot A \cdot \ln \left(i_{0}\right)-R_{f c} ; \\
V_{\text {nom }}=E_{o c}-N \cdot A \cdot \ln \left(\frac{I_{\text {nom }}}{i_{0}}\right)-R_{f c} \cdot I_{\text {nom }} \\
V_{\min }=E_{o c}-N \cdot A \cdot \ln \left(\frac{I_{\max }}{i_{0}}\right)-R_{f c} \cdot I_{\max },
\end{gathered}
$$

where $V_{1}, V_{\text {nom }}$ and $V_{\min }$ are voltages corresponding to currents $1 \mathrm{~A}, I_{\text {nom }}$ and $I_{\max }$ respectively.

$$
\begin{gathered}
a=\frac{N \cdot R \cdot T_{\mathrm{nom}}}{z \cdot F \cdot N \cdot A} ; \\
\Delta G=-R \cdot T_{\mathrm{nom}} \cdot \ln \left(\frac{i_{0}}{K_{1}}\right) ; \\
K_{1}=\frac{2 \cdot F \cdot k \cdot\left(P_{H_{2}(\mathrm{nom})}+P_{O_{2}(\mathrm{nom})}\right)}{h \cdot R} ; \\
P_{H_{2}(\mathrm{nom})}=x_{\mathrm{nom}} \cdot\left(1-U_{f H_{2}(\mathrm{nom})}\right) \cdot P_{f u e l(\mathrm{nom})} ; \\
P_{O_{2(\mathrm{nom})}}=y_{\mathrm{nom}} \cdot\left(1-U_{f O_{2}(\mathrm{nom})}\right) \cdot P_{\text {air }(\mathrm{nom})} ; \\
U_{f H}(\mathrm{nom}) \\
=\frac{\eta_{\mathrm{nom}} \cdot \Delta h \cdot\left(H_{2} O(g a s)\right) \cdot N}{2 \cdot F \cdot V_{\mathrm{nom}}} ; \\
U_{f O_{2(\mathrm{nom})}}=\frac{60000 \cdot R \cdot T_{\mathrm{nom}} \cdot N \cdot I_{\mathrm{nom}}}{2 \cdot z \cdot F \cdot P_{\text {air }(\mathrm{nom})} \cdot V_{\text {air }}(\mathrm{nom}) \cdot y_{\mathrm{nom}}} ; \\
K_{c}=\frac{E_{o c}}{E_{n(\mathrm{nom})}} ;
\end{gathered}
$$

$$
\begin{gathered}
E_{n(\mathrm{nom})}=\left.E_{n}\right|_{U_{f H_{2}}=U_{f H_{2}(\mathrm{nom})}, \quad U_{f O_{2}}=U_{f O_{2}(\mathrm{nom})}} \\
K_{f c}=\frac{V_{u}}{K_{c}\left(U_{f O_{2}(\max )}-U_{f O_{2}(\mathrm{nom})}\right)} \\
N \cdot A=\frac{\left(V_{1}-V_{\mathrm{nom}}\right) \cdot\left(I_{\max }-1\right)-\left(V_{1}-V_{\min }\right) \cdot\left(I_{\mathrm{nom}}-1\right)}{\ln \left(I_{\mathrm{nom}}\right) \cdot\left(I_{\max }-1\right)-\ln \left(I_{\max }\right) \cdot\left(I_{\mathrm{nom}}-1\right)} ; \\
R_{f c}=\frac{V_{1}-V_{\mathrm{nom}}-N \cdot A \cdot \ln \left(I_{\mathrm{nom}}\right)}{I_{\mathrm{nom}}-1} ; \\
i_{0}=\exp \left(\frac{V_{1}-E_{o c}+R_{f c}}{N \cdot A}\right)
\end{gathered}
$$

Equations (16), (17), (23) and (25) determine the FC parameters.

1.2. Polarization curve of the considered (PEMFC). The polarization curves are V-I and P-I characteristics specified by two distinguished regions: the activation region and the ohmic region. In the V-I polarization curve, four particulars voltages are showed: the open circuit voltage $E_{o c}$, the voltage $V_{1}$ corresponding to $1 \mathrm{~A}, V_{\text {nom }}$ and $V_{\min }$ corresponding to $i_{\max }$. In the P-I polarization curve, three main powers can be observed: $P_{\text {idle }}$ which is the power relating to $1 \mathrm{~A}, P_{\text {nom }}$ and $P_{\max }$. A typical polarization curves is depicted in Fig. 3 .

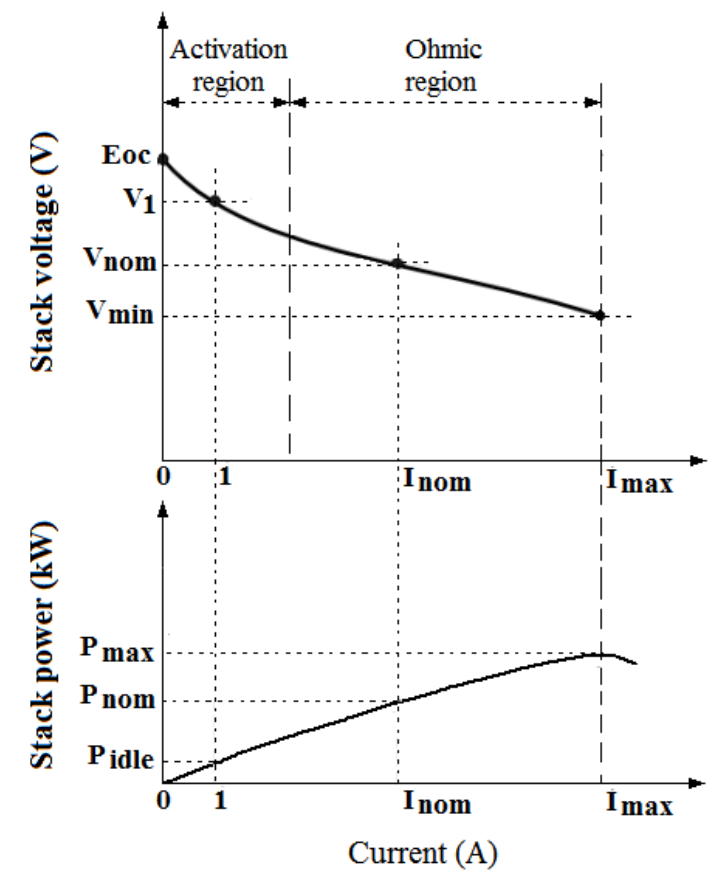

Fig. 3. Typical polarization curves

1.3. Validation of the Detailed Model. The dialog box of the FC SPS block allows to plot the ideal characteristics of one stack voltage and power vs. the stack current as shown in Fig. 4. These characteristics describe specific points corresponding to the nominal and the maximum currents which values are respectively $45 \mathrm{~V}, 37 \mathrm{~V}$ (which corresponds to the values mentioned in Table 1), $5.9985 \mathrm{~kW}, 8.325 \mathrm{~kW}$. In this contribution, four stacks of PEMFCs are considered and which specifications are reported in Table 1 [17]. 

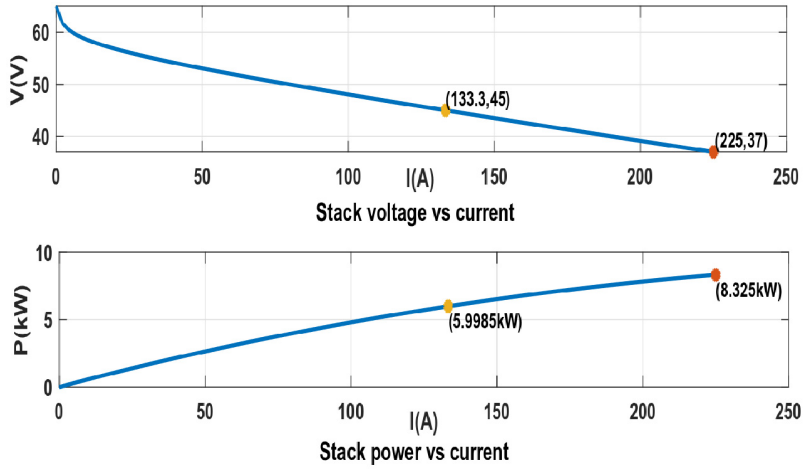

Fig. 4. Polarization curves of the considered stack

Table 1

Parameters of the preset $6 \mathrm{~kW} / 45 V_{d c}$ fuel cell stack model

\begin{tabular}{|c|c|}
\hline Parameter & Value \\
\hline$\left[E_{o c}, V_{1}\right], \mathrm{V}$ & {$[65,63]$} \\
\hline$\left[I_{\text {nom }}, V_{\text {nom }}\right], \mathrm{A}, \mathrm{V}$ & {$[133.3,45]$} \\
\hline$\left[I_{\max }, V_{\min }\right], \mathrm{A}, \mathrm{V}$ & {$[225,37]$} \\
\hline$N$ & 65 \\
\hline$\eta_{\text {nom }}, \%$ & 55 \\
\hline$T_{\text {nom }},{ }^{\circ} \mathrm{C}$ & 65 \\
\hline$V_{\text {airnom }}, 1 / \mathrm{min}$ & 300 \\
\hline$\left[P_{\text {fuelnom }}, P_{\text {airnom }}\right]$, bar & {$[1.5,1]$} \\
\hline$z$ & 2 \\
\hline$\left[x_{\text {nom }}, y_{\text {nom }}, w_{\text {nom }}\right], \%$ & {$[99.95,21,1]$} \\
\hline$T_{d}, \mathrm{~s}$ & 1 \\
\hline
\end{tabular}

2. Battery model. A battery is a device composed of one or more electrochemical cells that convert electrical energy into chemical energy during charging and the inverse during discharging where the electrolytes are able to move as ions within allowing the chemical reactions to be completed. Batteries have virtues of fast response speed, high ramp rates, easily sited, modular and good energy efficiency [18]. There are three main sorts of batteries: lead acid, nickel-based, and lithium-based [19]. The battery considered in this paper is of type Nickel-Metal-Hydride (Ni-MH) as they have proven to exhibit high energy density and efficiency, low prices and safety [20].

2.1. Modeling of the Ni-MH battery. The SPS battery model is the approach proposed in [21] and which is shown in Fig. 5. This model is selected for this paper and the main equations are as follows [22, 23]. The battery voltage either in charge or discharge modes is expressed by:

$$
V_{\text {batt }}=E_{\text {batt }}-R_{\text {batt }} \cdot i
$$

where

$$
E_{\text {batt }}=\left\{\begin{array}{l}
E_{0}-K_{\text {batt }} \frac{Q}{Q-i \cdot t} \cdot\left(i \cdot t+i^{*}\right)+\operatorname{Exp}(t) \\
- \text { in discharge mode; } \\
E_{0}-K_{\text {batt }} \frac{Q}{Q-i t} \cdot i \cdot t-K_{\text {batt }} \frac{Q}{|i \cdot t|-0.1 \cdot Q} \cdot i^{*}+\operatorname{Exp}(t) \\
- \text { in charge mode; }
\end{array}\right.
$$

$$
\stackrel{\bullet}{\operatorname{Exp}}(t)=V_{\text {batt }}|i \cdot t| \cdot\left(-\operatorname{Exp}(t)+A_{\text {batt }} \cdot u(t)\right),
$$

where $V_{\text {batt }}$ - battery voltage, $\mathrm{V} ; E_{0}$ - battery constant voltage, $\mathrm{V} ; K_{\text {batt }}-$ polarization constant, $\mathrm{V} / \mathrm{A} \cdot \mathrm{h}$; $Q$ - battery capacity, A.h; $i \cdot t=\int i d t-$ actual battery charge, A.h; $A_{\text {batt }}-$ exponential zone amplitude, V; $B_{\text {batt }}-$ exponential zone time constant inverse $(\mathrm{A} \cdot \mathrm{h})^{-1}$; $R_{\text {batt }}$ - internal resistance of the battery, $\Omega ; i$ - battery current, A; $i^{*}-$ filtered current, A; $\operatorname{Exp}(t)$ - exponential zone voltage, $\mathrm{V} ; i(t)$ - battery current, $\mathrm{A} ; u(t)$ - charge or discharge mode

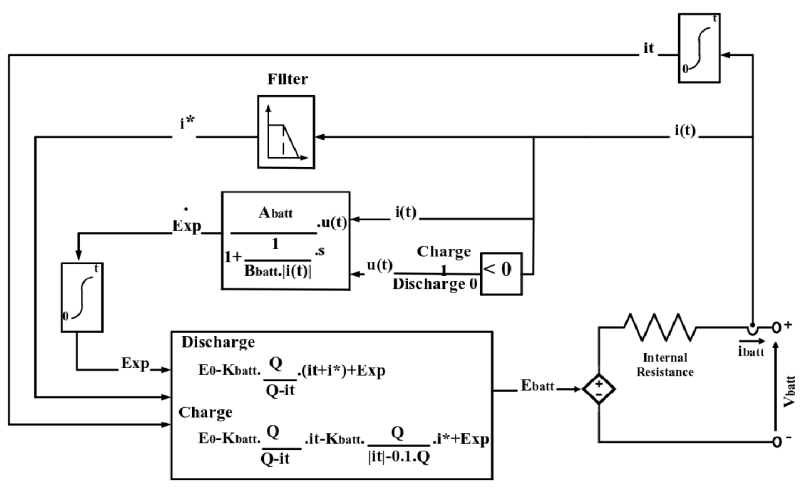

Fig. 5. Ni-MH battery model

2.2. Discharge and charge curves. Typical discharge and charge characteristics are illustrated in Fig. 6.
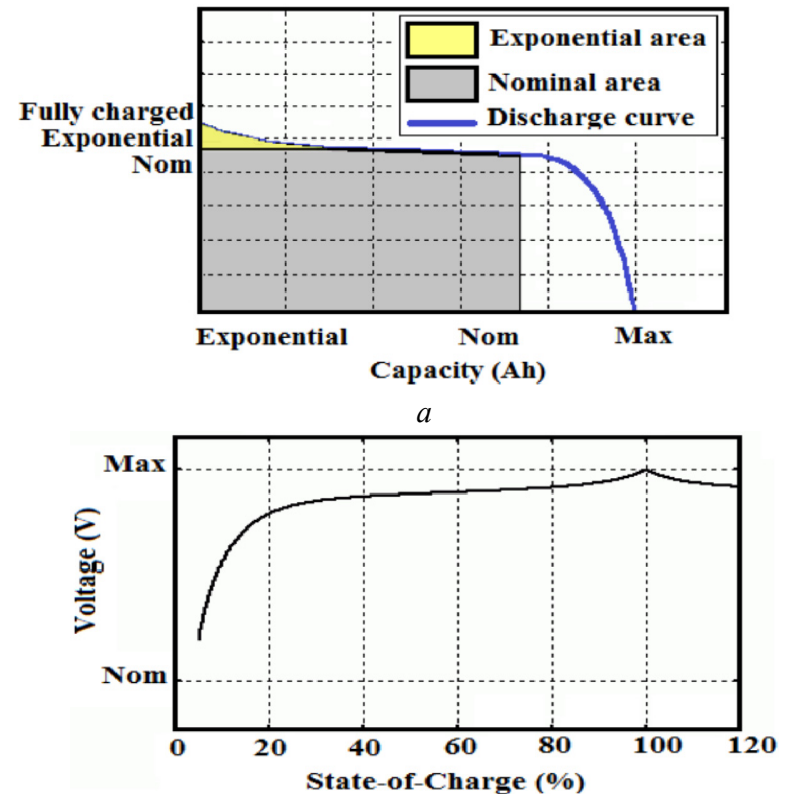

$b$

Fig. 6. Typical discharge and charge characteristics: discharge curve $(a)$ and charge curve $(b)$

The discharge curve of battery voltage vs. capacity contains three zones (Fig. 6,a): the first zone (exponential area) where the voltage drops exponentially when the battery is charged; the second zone (nominal area) illustrating the charge that can be extracted from the battery until the voltage drops below the nominal value; the third part (discharge) which shows the total discharge of the battery when the voltage diminishes rapidly.

The charge curve of battery voltage vs. the State-OfCharge (SOC) is depicted in Fig. 7. It describes four zones: 
- zone I: $5 \%<\mathrm{SOC}<20 \%$, where the voltage increases rapidly;

- zone II: $20 \%<\mathrm{SOC}<80 \%$, where the voltage increases very slowly;

- zone III: $80 \%<$ SOC $<100 \%$, where the voltage starts to increase exponentially;

- zone IV: SOC > $100 \%$, a new cycle of exponential discharge begins.

2.3. Validation of the model. The parameters required by the model are illustrated in Table 2 extracted from Panasonic NiMH-HHR650D battery data sheet. The simulated discharge curves of the considered battery are shown in Fig. 7. The upper curve concerns the discharge for the nominal current where the three zones are clearly highlighted. The lower curves display the discharge characteristic for different currents (70 A, 90 A, 117 A). It is obvious that more the current is bigger more the discharge is faster.

Table 2

Battery model input parameters

\begin{tabular}{|c|c|}
\hline Parameter & Value \\
\hline$V_{\text {battnom }}, \mathrm{V}$ & 180 \\
\hline$Q_{\text {nom }}, \mathrm{A} \cdot \mathrm{h}$ & 585 \\
\hline$Q_{\text {max }}, \mathrm{A} \cdot \mathrm{h}$ & 630 \\
\hline$V_{\text {battmax }}, \mathrm{V}$ & 212 \\
\hline$I_{\text {disnom }} \mathrm{A}$ & 117 \\
\hline$R, \Omega$ & 0.0030769 \\
\hline$\left[V_{\text {battexp }}, Q_{\text {exp }}\right], \mathrm{V}, \mathrm{A} \cdot \mathrm{h}$ & {$[195.25117]$} \\
\hline Initial SOC, $\%$ & 85 \\
\hline$t_{r}, \mathrm{~s}$ & 30 \\
\hline
\end{tabular}

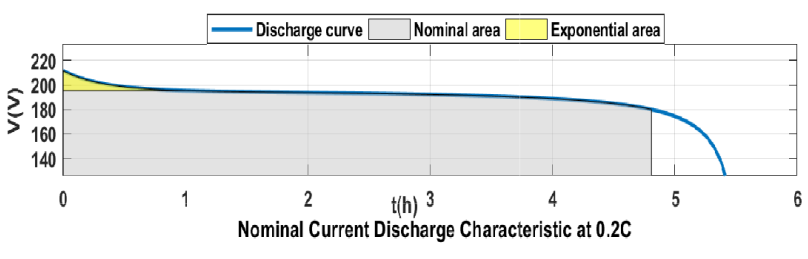

$-70 \mathrm{~A} \ldots \ldots . \cdots .69 \mathrm{~A}-117 \mathrm{~A}$

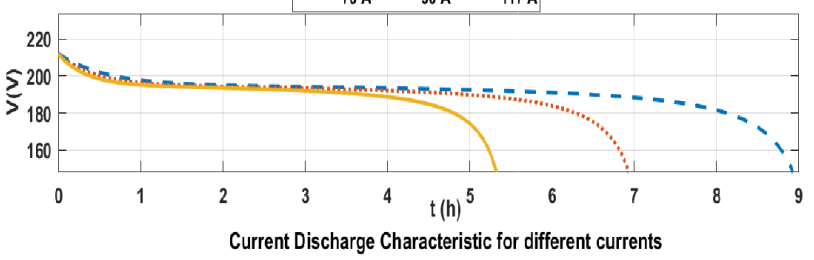

Fig. 7. Discharge curves of the considered battery

DC/DC converters models and control circuits. In this section models and control circuits of DC/DC converters used as interface between the hybrid FC/battery and the active power filter DC buses are presented. The considered DC/DC converters are operating in unidirectional boost mode for the $\mathrm{FC}$ and in bidirectional boost/buck modes for the battery (boost mode for discharging and buck mode for charging).

1. Models of DC/DC converters power circuits. In this part the average model is adopted since it is less timeconsuming as the switches are substituted by controlled voltage and current sources [24].

Figure 8 shows the average models of the DC/DC converters. Figure 8, $a$ concerns the buck mode whereas
Fig. 8,b illustrates the boost mode, where $\alpha_{\text {boost }}, \alpha_{\text {buck }}$ are duty cycles of boost and buck modes respectively; $\eta$ - efficiency, $\% ; V_{i}, V_{\mathrm{o}}$ are input and output measured voltages, $\mathrm{V} ; I_{i}, I_{\mathrm{o}}$ are input and output measured currents, A; $L$ - smoothing inductance, $\mathrm{H} ; C$ - filtering capacity, F.
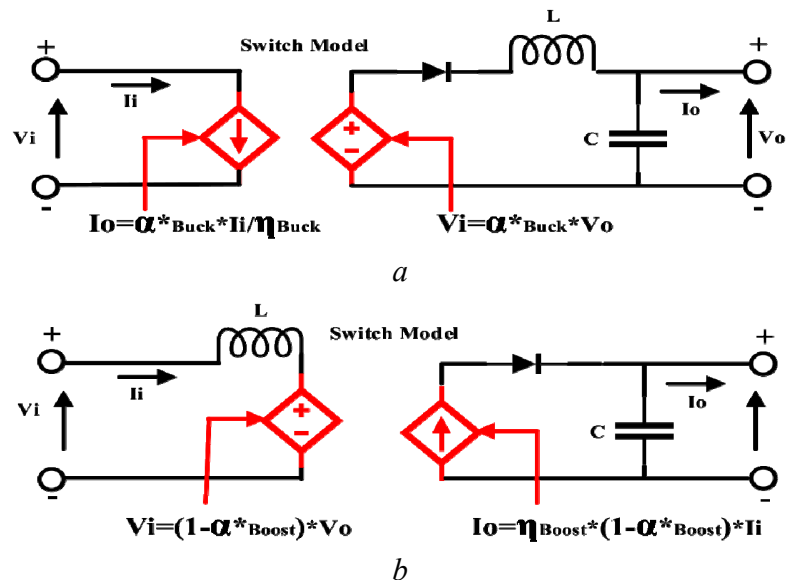

Fig. 8. DC/DC Power circuit buck mode $(a)$ and boost mode $(b)$

2. Control circuits. The principle of the control circuit is to provide both the FC and the battery with their respective input reference currents $\left(I_{f c}^{*}, I_{b a t t}^{*}\right)$ as mentioned in Fig. 1. For that, the control approach is organized in two steps: generating at first the output reference voltages $\left(V_{o f c}^{*}, V_{o B a t t}^{*}\right)$ and then the input reference currents $\left(I_{i f c}^{*}, I_{i B a t t}^{*}\right)$. The first step is carried-out from the algorithm of energy management. The second step is performed in the block of input reference current on-line identification.

2.1. Energy management algorithm. The idea of this algorithm was inspired from [19] related to hybrid electric vehicle system. The algorithm receives data about the demand power measured at the DC/DC converters terminals $\left(P_{d e m}\right)$ and the battery state of charge (SOC), then it realizes energy management in such a way to express reference FC and battery powers $\left(P^{*}{ }_{f c}, P^{*}{ }_{b a t t}\right)$ depending on the SOC rate. The algorithm inputs also values of FC idle, low and high powers $\left(P_{f_{c} \text { idle }}, P_{f_{c} \text { low }}\right.$, and $P_{f c}$ high $)$ and battery maximum power $\left(P_{\text {batt max }}\right)$. As resumed in Fig. 9, different situations can be considered according to the demand power rate (high, medium, low) and the state of charge of battery (discharged - SOC $<40$ $\%$, little charged - SOC $>40 \%$, high charged - SOC < $80 \%$, and completely charged - SOC $>80 \%$ ).

High demand power $P_{f c h i g h}<P_{d e m}<P_{f_{c} \text { high }}+P_{b a t \text { max }}$.

- If SOC $<40 \%$. The battery can't provide power to satisfy the high demand. Then, the FC can just feed the DC bus and can't ensure power to charge the battery:

$$
P_{f c}^{*}=P_{d e m}, P_{\text {batt }}^{*}=0 .
$$

- If SOC $>40 \%$. The battery can contribute to satisfy $P_{\text {dem }}$.

- If $P_{d e m}$ is very high $P_{d e m}>P_{f c h i g h}+P_{b a t \text { max }}$. The battery and the FC work together for feeding the DC bus (hybrid powering): $P_{f c}^{*}=P_{d e m}-P_{b a t t}, P_{\text {batt }}^{*}=P_{b a t \max }$.

- If $P_{d e m}$ is high $P_{f c h i g h}<P_{d e m}<P_{f c h i g h}+P_{b a t \max }$. The battery continues to help the FC to feed the DC bus (hybrid powering): $P_{f c}^{*}=P_{f c h i g h}, P^{*}{ }_{b a t t}=P_{f c}^{*}-P_{d e m}$. 
Medium demand power $P_{\text {low }}<P_{\text {dem }}<P_{f c h i g h}$.

- If SOC $<80 \%$. Since the demand power is less high and the battery is not completely charged. Thus, the FC power can simultaneously satisfy $P_{d e m}$ and charge the battery: $P_{f_{c}}^{*}=P_{f c h i g h}, P_{\text {batt }}^{*}=P_{f_{c}}^{*}-P_{\text {dem }}$.

- If SOC $>80 \%$. In this case, the battery is completely charged. So, there is no need to share the FC power between the DC bus and the battery: $P^{*}{ }_{f c}=P_{d e m}, P^{*}{ }_{b a t t}=0$.
Low demand power $P_{\text {idle }}<P_{\text {dem }}<P_{\text {low }}$.

- If SOC $<80 \%$. The battery lacks of little amount of charge. Then it needs to be charged from the FC even $P^{*}{ }_{f c}$ is low. Accordingly $P_{f c}^{*}$ will be shared between $P_{d e m}$ and $P_{\text {batt }}^{*}: P_{f_{c}}^{*}=P_{\text {fclow }}, P^{*}{ }_{\text {batt }}=P^{*}{ }_{f c}-P_{\text {dem }}$.

- If SOC $>80 \%$. The major amount of power needed from the DC bus comes from the completely charged battery, the FC being at its weakest power $P_{f c \text { idle }}: P_{f c}^{*}=P_{f c \text { idle }}, P^{*}{ }_{\text {batt }}=P_{\text {dem }}-P_{f c}^{*}$.

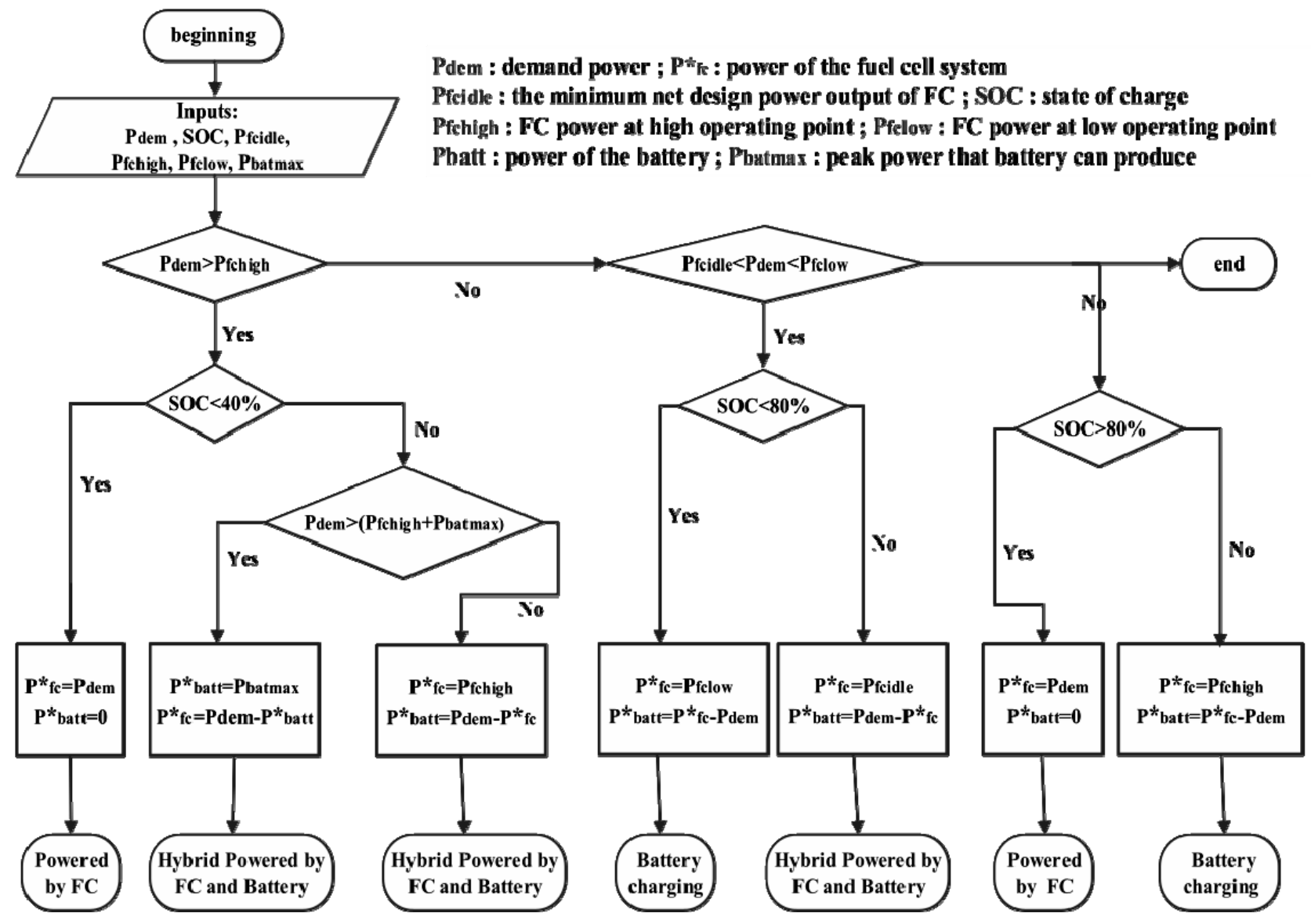

Fig. 9. Energy management algorithm

Once the FC and battery reference powers are carried-out from algorithm. Reference voltage can be easily deduced from:

$$
\begin{aligned}
V_{o f c}^{*} & =\frac{P_{f c}^{*}}{I_{o f c}} ; \\
V_{o b a t t}^{*} & =\frac{P_{b a t t}^{*}}{I_{\text {obatt }}} .
\end{aligned}
$$

To determine $P_{f_{c} \text { idle }}, P_{f_{c} \text { low }}$, and $P_{f_{c} \text { high }}$, one can use the characteristics showed in Fig. 10 representing one cell voltage, one stack net power density and one stack efficiency vs. one cell current. $P_{\text {fcidle }}$ is the power corresponding to $1 \mathrm{~A} . P_{f_{c} \text { low }}$ and $P_{f_{c} \text { high }}$ are the powers around $50 \%$ of the efficiency curve (in it rising and falling regions respectively) obtained at $50 \%$ of the nominal current.

Considering a $24 \mathrm{FC}$ of 4 series connected stacks $\mathrm{kW}$ (each stack is rated at $6 \mathrm{~kW}, 45 \mathrm{~V}$ ). Then, $P_{f_{c} \text { idle }}, P_{f_{c}}$ low, and $P_{f_{c} \text { high }}$ can be deduced by multiplying the stack specific powers extracted from Fig. 11 by 4 . formula:

To obtain $P_{\text {batt max }}$, one can use the following $P_{\text {batt } \max }=V_{\text {batt } \max } \cdot I_{\text {disnom }}$,

where $V_{\text {batt max }}$ - fully charged voltage, $\mathrm{V} ; I_{\text {disnom }}$ - nominal discharge current, $\mathrm{A}$.

2.2. Input reference current on-line identification. The DC/DC converter input current can be subtracted from the efficiency formula given by:

$$
\eta=\frac{P_{o}}{P_{i}}=\frac{I_{o} \cdot V_{o}}{I_{i} \cdot V_{i}} .
$$

For the reference input current, one can substitute $I_{i}$ by $I_{i}^{*}$ and $V_{o}$ by $V_{o}^{*}$, this latter is provided by the algorithm which justifies the on-line aspect in this identification:

$$
\begin{array}{r}
I_{i}^{*}=\frac{I_{o} \cdot V_{o}^{*}}{V_{i} \cdot \eta_{\text {boost }}}, \text { boost mode } \\
I_{i}^{*}=\frac{I_{O} \cdot V_{o}^{*} \cdot \eta_{b u c k}}{V_{i}}, \text { buck mode } .
\end{array}
$$




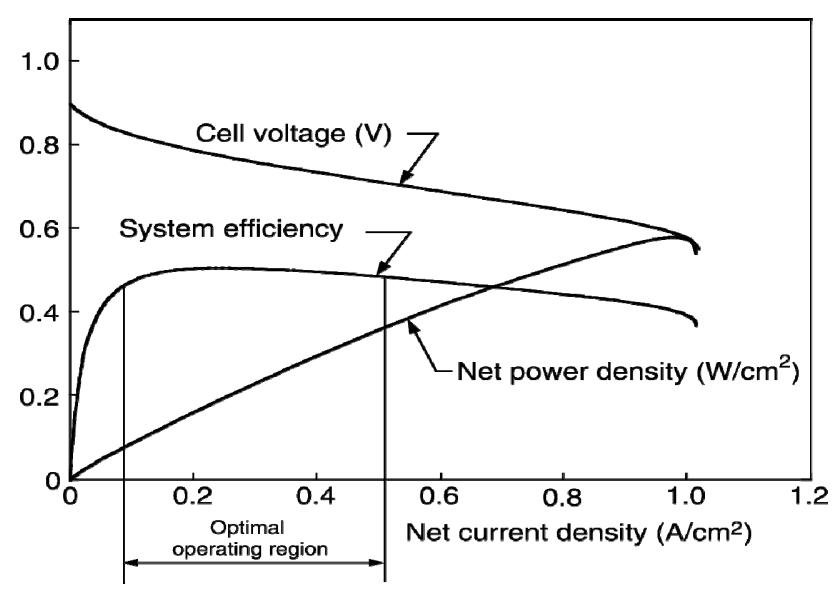

Fig. 10. Typical operating characteristics of a fuel cell system

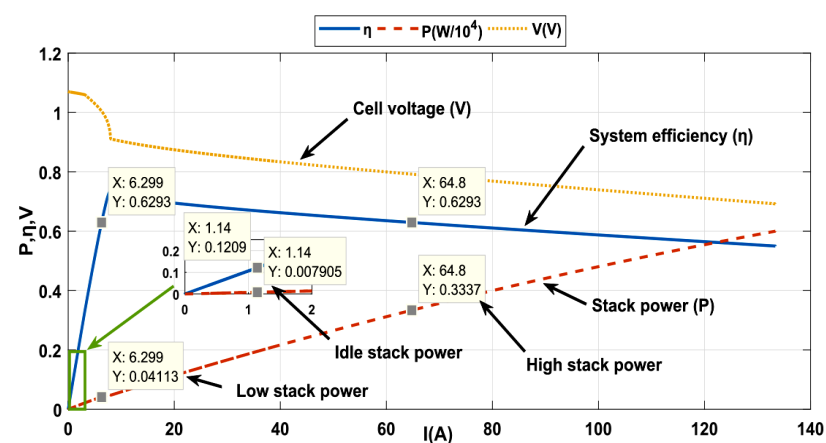

Fig. 11. Operating characteristics of the considered stack

To obtain the efficiency $(\eta)$, a two dimensional mapping data (Fig. 12) provided by the manufacturer BRUSA BDC546 DC/DC converter is adopted [25]. The data was implemented in 2-D look-up tables having in their entries the duty cycle $\alpha$ of the considered mode and the output current $I_{0}$. The duty cycles of boost and buck modes are respectively given by:

$$
\begin{gathered}
\alpha_{\text {boost }}=1-\frac{V_{o}}{V_{i}} ; \\
\alpha_{\text {buck }}=\frac{V_{o}}{V_{i}} .
\end{gathered}
$$

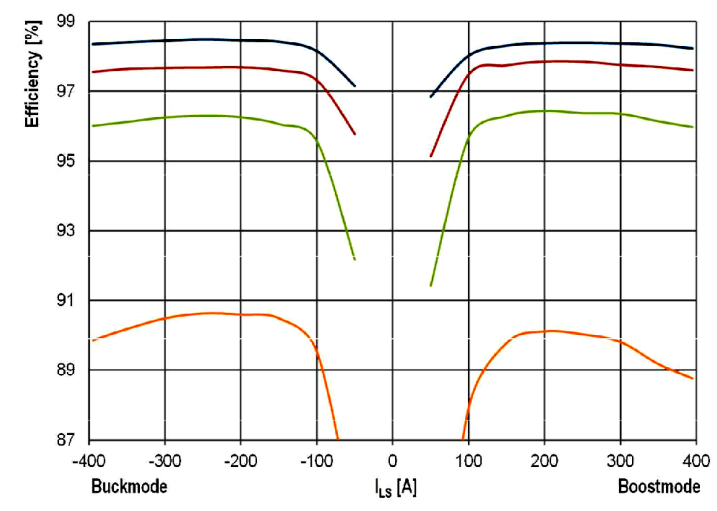

Fig. 12. Power DC/DC efficiency map [25]

The block schemes of the on-line reference input current identification in both modes boost and buck are depicted in Fig. 13.

The unidirectional DC/DC converter operates only in the boost mode during powering mode for delivering the power required by the load while the bidirectional DC/DC converter operates both in boost and buck modes during powering and charging modes.

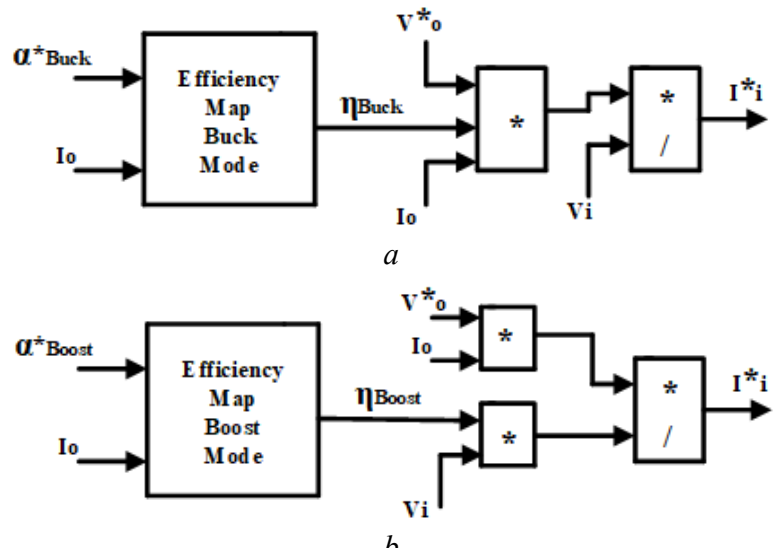

Fig. 13. DC/DC control circuit buck mode (a) and boost mode (b)

Simulation results discussion. In this section simulation works about the previous study are presented. They were carried out using MATLAB/Simulink software and considering the parameters reported in Table 3.

Table 3

Simulation parameters

\begin{tabular}{|c|c|}
\hline Parameter & Value \\
\hline$P_{\text {fcnom }}$ & $24 \mathrm{~kW}$ \\
\hline$P_{\text {batmax }}$ & $21 \mathrm{~kW}$ \\
\hline$P_{\text {fcidle }}$ & $316.2 \mathrm{~W}$ \\
\hline$P_{\text {fclow }}$ & $1.6452 \mathrm{~kW}$ \\
\hline$P_{\text {fchigh }}$ & $13.348 \mathrm{~kW}$ \\
\hline$\alpha_{\text {fcboost }}$ & {$[0.45,0.51,0.81,0.81,0.9,0.7,0.58]$} \\
\hline$\alpha_{\text {battboost }}$ & {$[0.5,0,0.83,0,0.88,0,0]$} \\
\hline$\alpha_{\text {battbuck }}$ & {$[0,0.38,0,0,0,0.29,0]$} \\
\hline SOC & {$[85,70,50,35,50,70,85](\%)$} \\
\hline
\end{tabular}

The principle of the simulations studies consists to impose time varying duty cycles $\left(\alpha_{f c b o o s t}, \alpha_{\text {battboost }}\right.$ and $\left.\alpha_{\text {battbuck }}\right)$ and SOC then to extract the corresponding input and output DC/DC converters voltages, reference powers $\left(P^{*}{ }_{\text {dem }}, P^{*}{ }_{f c}, P^{*}{ }_{\text {batt }}\right)$ and measured powers $\left(P_{\text {dem }}, P_{f c}, P_{b a t t}\right)$. Finally, the measured powers are compared to the reference powers.

Figure 14 represents the imposed duty cycles and SOCs. In some time intervals one can observe that $\alpha_{\text {battboost }}$ takes the value 0 , this occurs when the battery is incapable to help the FC to satisfy $P_{d e m}$ (case of SOC $<40 \%$ and $P_{\text {dem }}>P_{\text {fchigh }}$ ) or when $P_{\text {dem }}$ is not high, then the FC has no need to the battery help (case of SOC $>80 \%$ and $P_{d e m}<P_{\text {fclow }}$ ), or when $P_{d e m}$ is very low and the battery SOC is little inferior to $80 \%$ (case of SOC $<80 \%$ and $\left.P_{\text {dem }}<P_{\text {fclow }}\right)$, or when $P_{\text {dem }}$ is quite low and SOC is also little inferior to $80 \%$ (case of SOC $<80 \%$ and $\left.P_{\text {dem }}>P_{\text {fclow }}\right)$. The same observation can be pointed out with $\alpha_{\text {battbuck }}$ which values are different to 0 only when the battery is charging from the FC (case SOC $<80 \%$ and $P_{\text {dem }}<P_{\text {fclow }}$ or SOC $<80 \%$ and $P_{\text {dem }}>P_{\text {fclow }) \text {, otherwise, }}$ it is takes the value 0 . Consequently, the battery 
converters do not work all time. They work only when the battery power is required to help the FC to satisfy $P_{d e m}$ provided that the SOC is comprised between $40 \%$ and 80 $\%$ or when the battery is in charging mode (the SOC is little inferior to $80 \%$ and $P_{d e m}<P_{f_{c}}$ ).
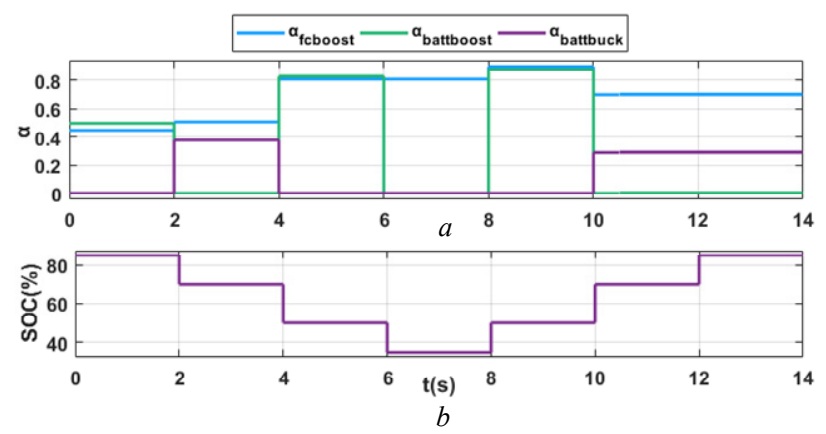

Fig. 14. Duty cycles of DC/DC FC and battery converters $(a)$ and state of charge (SOC) $(b)$

Figure 15 shows the obtained output voltages of DC/DC FC and battery boost converters and DC/DC battery buck converter. It is obvious that the $\mathrm{FC}$ boost converter works all time since its output voltage $V_{0 f c}$ is continuously greater than its input voltage $V_{i f c}$ as illustrated in Fig. 15,a. However, the battery DC/DC boost converter operates only when the $\mathrm{FC}$ is incapable to fulfill $P_{d e m}$ alone and when SOC is grater than $40 \%$ or 80 $\%$. As shown in Fig. 15,b, from the beginning to $5 \mathrm{~s}$, the FC power is very low $\left(P_{f_{c}}=P_{\text {fcidle }}\right)$ whereas $P_{\text {fcidle }}<P_{\text {dem }}<P_{\text {fclow }}$ then, the battery is switched on to compensate the lack of power. Similarly, it is switched on once again between $10 \mathrm{~s}$ and $15 \mathrm{~s}$ when $P_{\text {dem }}$ is high $\left(P_{\text {dem }}>P_{\text {fchigh }}\right)$, then the FC can not feed the DC bus alone which involves the help of the battery in order to satisfy $P_{d e m}$. Finally, the battery is once more switched on when $P_{\text {dem }}$ is very high $\left(P_{\text {dem }}>P_{\text {fchigh }}+P_{\text {battmax }}\right)$ from 20 to $25 \mathrm{~s}$. All these situations result in the battery boost voltage presented in Fig. 15,c where $V_{0 b a t t 1}$ is sometimes equal to $V_{\text {ibatt } 1}$ when the battery is switched off $\left(\alpha_{\text {battboost }}=0\right)$, otherwise it is always greater than $V_{\text {ibatt } 1}$ when the battery is switched on $\left(\alpha_{\text {battboost }} \neq 0\right)$. Now, when $P_{\text {dem }}$ is low $\left(P_{\text {fcidle }}<P_{\text {dem }}<P_{\text {fclow }}\right)$ and quite low $\left(P_{\text {fclow }}<P_{\text {dem }}<P_{\text {fchigh }}\right)$ and SOC is little inferior to $80 \%$, the $\mathrm{DC} / \mathrm{DC}$ buck converter is operational to charge the battery; this occurs between $5 \mathrm{~s}$ and $10 \mathrm{~s}$ and between $25 \mathrm{~s}$ and $30 \mathrm{~s}$ as depicted in Fig. 15,c. Finally, Fig. 15,d shows the obtained demand voltage $V_{d e m}$ which is all time equal to $V_{0 f c}, V_{0 b a t t 1}$ and $V_{\text {ibatt } 2}$ since the outputs of the FC and the battery boost converters are connected in parallel with the input of the battery DC/DC buck converter.

In Fig. 16, the currents curves are presented. In each one of parts ( $a, b$ and $c$ ) of this Fig. 16 is plotted the measured input current and its reference and the measured output current of each converter. The most important observation is the perfect agreement between the input current and its reference. Figure 16, $d$ represents the demand current which max value is 30 A corresponding the $\max V_{d c \max } 1550 \mathrm{~V}$ giving an apparent power of $48.6 \mathrm{kVA}$.
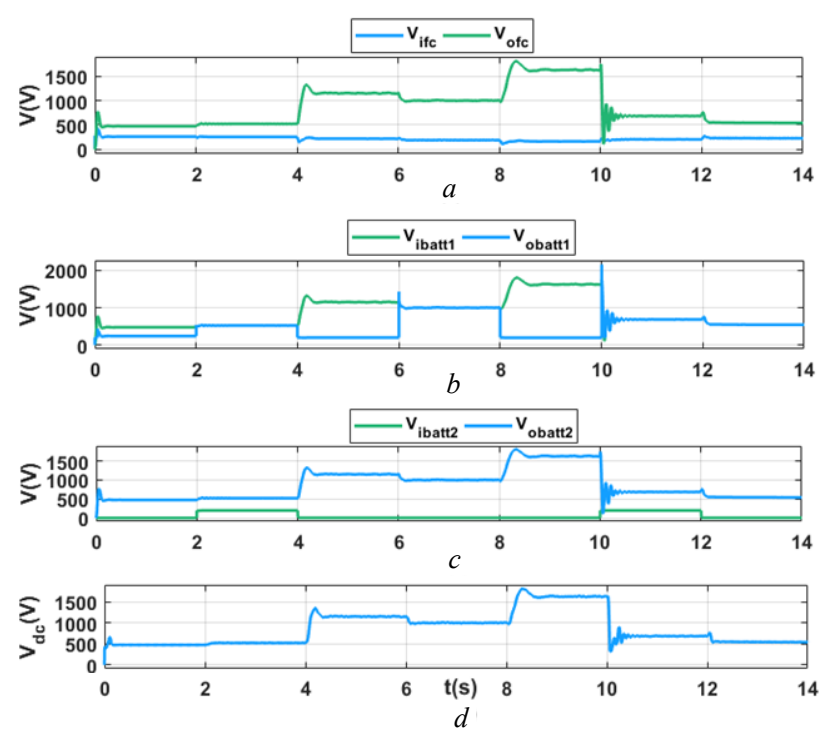

Fig. 15. Input and output voltages of DC/DC converters DC/DC FC boost converter $(a), \mathrm{DC} / \mathrm{DC}$ battery boost converter $(b)$, DC/DC battery buck converter $(c)$, and demand voltage $(d)$
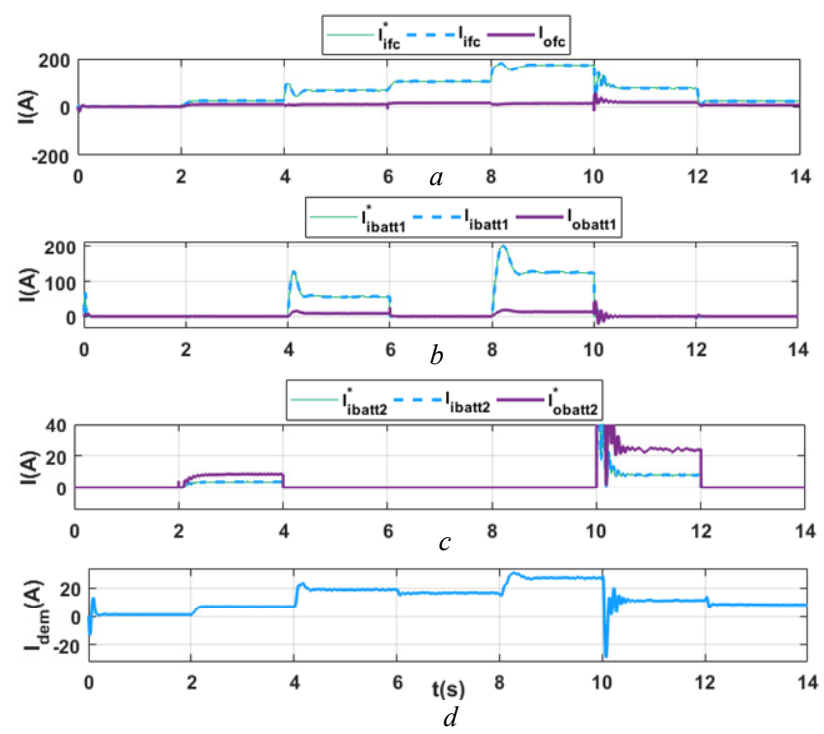

Fig. 16. Input and output currents of DC/DC converters DC/DC FC boost converter $(a), \mathrm{DC} / \mathrm{DC}$ battery boost converter $(b)$, DC/DC battery buck converter $(c)$, and demand current $(d)$

The last set of figures (Fig. 17) concerns the measured powers curves of the FC (Fig. 17,a), the battery (Fig. 17,b) and the demand (Fig. 17,c) and their respective reference powers.

As first statement measured powers and their corresponding references are almost tighten most of the time. Indeed, one can see a good settlement between FC and battery powers and their references $P_{f c}^{*}, P^{*}$ batt (Fig. 17,a, Fig. 17,b) especially when $P_{\text {dem }}$ is low $\left(P_{\text {fidle }}<P_{\text {dem }}<P_{\text {fclow }}\right)$ and medium $\left(P_{\text {fclow }}<P_{\text {dem }}<P_{\text {fchigh }}\right)$, however, $P_{d e m}$ and its reference $P_{\text {dem }}^{*}$ are perfectly tighten all time (Fig. 17,c).

Recall that reference powers are delivered from energy management algorithm developed in previous section. 

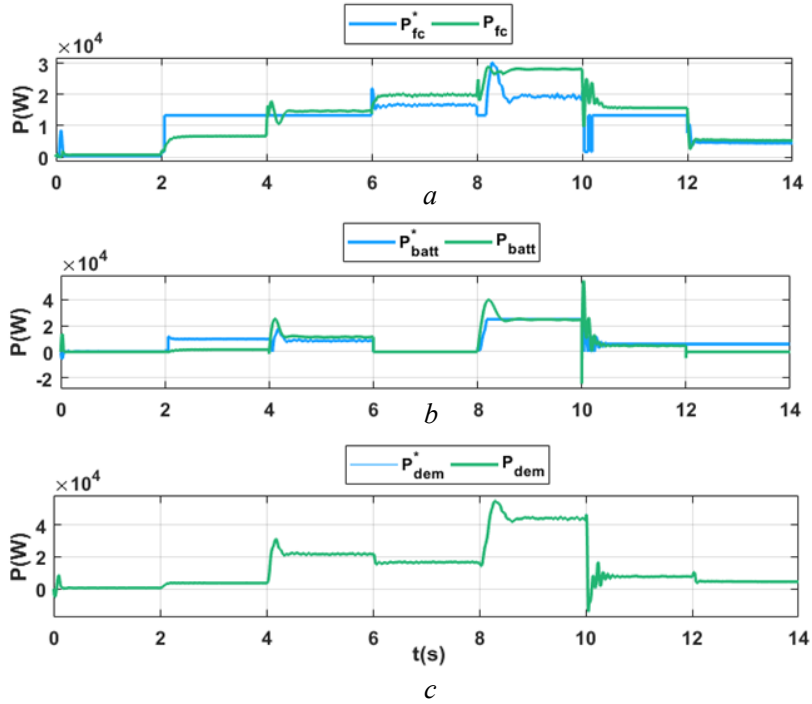

Fig. 17. Reference and measured powers of fuel cell (a), battery $(b)$, and demand $(c)$

Conclusion.

The work, presented in this paper, concerns a hybrid FC/battery DC power system.

Firstly, theoretical studies about FC and battery systems are stated.

Secondly, the adopted average models of boost and buck FC and battery DC/DC converters and their control strategies are exposed where a big focus is given to the innovated energy management algorithm and the input DC/DC converters reference currents on-line identification using the efficiency map-based method.

Finally, the presented works are numerically verified through computer MATLAB/Simulink simulations. The studies are based on an adequate choice of the DC/DC converters duty cycles and the battery SOC, as well as the $\mathrm{FC} /$ battery specific powers $\left(P_{\text {fchigh }}, P_{\text {fclow }}, P_{\text {fcidle }}, P_{\text {battmax }}\right)$. The battery converters are functional only when the battery is needed to help the FC to satisfy $P_{d e m}$ provided that (SOC $>80 \%$ or SOC $>40 \%$ ) or when the battery SOC is little inferior to $80 \%$ and the FC power is greater than $P_{\text {dem }}$.

All these situations are summarized in Table 4.

The obtained results demonstrate the algorithm satisfactory operation.

Conditions of battery DC/DC converters working

\begin{tabular}{|c|c|c|}
\hline & $\alpha_{\text {fcboost }}$ & $\alpha_{f c b o o s t}$ \\
\hline $\begin{array}{c}P_{\text {fcidle }}<P_{\text {dem }}<P_{\text {fclow }}, P_{f c}=P_{\text {fcidle }} \\
\text { SOC }>80 \%\end{array}$ & $\neq 0$ & $=0$ \\
\hline $\begin{aligned} P_{f c h i g h} & <P_{\text {dem }}<P_{\text {fchigh }}+P_{\text {batmax }} \\
P_{f c} & =P_{f c h i g h}, \text { SOC }>40 \%\end{aligned}$ & $\neq 0$ & $=0$ \\
\hline $\begin{array}{c}P_{\text {dem }}>P_{\text {fchigh }}+P_{\text {batmax }}, P_{f c}=P_{\text {fchigh }}, \\
\text { SOC }>40 \%\end{array}$ & $\neq 0$ & $=0$ \\
\hline $\begin{array}{c}P_{\text {fcidle }}<P_{\text {dem }}<P_{f c l o w}, P_{f c}=P_{\text {fclow }} \\
\text { SOC }<80 \%\end{array}$ & $=0$ & $\neq 0$ \\
\hline $\begin{array}{c}P_{\text {fclow }}<P_{\text {dem }}<P_{\text {fchigh }}, P_{f_{c}}=P_{\text {fchigh }}, \\
\text { SOC }<80 \%\end{array}$ & $=0$ & $\neq 0$ \\
\hline $\begin{array}{c}P_{f c h i g h}<P_{\text {dem }}<P_{\text {fchigh }}+P_{\text {batmax }} \\
P_{f c}=P_{f c h i g h}, \text { SOC }<40 \%\end{array}$ & $=0$ & $=0$ \\
\hline $\begin{array}{c}P_{\text {fclow }}<P_{\text {dem }}<P_{\text {fchigh }}, P_{f c}=P_{\text {fchigh }}, \\
\text { SOC }>80 \%\end{array}$ & $=0$ & $=0$ \\
\hline
\end{tabular}

The continuation of the contribution concerns the use of the managed $P_{d e m}$ to feed a three-level shunt active power filter (3L-SAPF) and to study the impact on the power quality. Moreover, development of a regulation loops to carry out the DC/DC converters duty cycles automatically is envisaged. Also, energy efficiency study of the whole system is being considered.

\section{REFERENCES}

1. Odeim F., Roes J., Heinzel A. Power management optimization of a fuel cell/battery/supercapacitor hybrid system for transit bus applications. IEEE Transactions on Vehicular Technology, 2016, vol. 65, no. 7, pp. 5783-5788. doi: 10.1109/TVT.2015.2456232.

2. Matthey J. Fuel cell today. The leading authority on fuel cells. Available at: http://www.fuelcelltoday.com (accessed 08 March 2020).

3. Sun L., Wu G., Xue Y., Shen J., Li D., Lee K.Y. Coordinated control strategies for fuel cell power plant in a microgrid. IEEE Transactions on Energy Conversion, 2018, vol. 33, no. 1, pp. 1-9. doi: 10.1109/TEC.2017.2729881.

4. Thounthong P., Rael S., Davat B. Control algorithm of fuel cell and batteries for distributed generation system. IEEE Transactions on Energy Conversion, 2008, vol. 23. no. 1, pp. 148-155. doi: 10.1109/TEC.2006.888028.

5. Boscaino V., Collura R., Capponi G., Marino F. A fuel cellbattery hybrid power supply for portable applications. SPEEDAM 2010, Pisa, 2010, pp. 580-585. doi: 10.1109/SPEEDAM.2010.5542091.

6. Lai J.-S., Ellis M.W. Fuel cell power systems and applications. Proceedings of the IEEE, 2017, vol. 105, no. 11, pp. 2166-2190. doi: 10.1109/JPROC.2017.2723561.

7. Hong Z., Zhu Y., Shang W., Li Q., Chen W. Research of energy management strategy for fuel cell/battery hybrid locomotive. 2017 IEEE Transportation Electrification Conference and Expo, Asia-Pacific (ITEC Asia-Pacific), 2017, pp. 1-5. doi: 10.1109/ITEC-AP.2017.8080852

8. Li Y.H., Rajakaruna S., Choi S.S. Control of a solid oxide fuel cell power plant in a grid-connected system. IEEE Transactions on Energy Conversion, 2007, vol. 22, no. 2, pp. 405-413. doi: 10.1109/TEC.2005.853756.

9. Vural B., Dusmez S., Uzunoglu M., Ugur E., Akin B. Fuel consumption comparison of different battery/ultra capacitor hybridization topologies for fuel-cell vehicles on a test bench. IEEE Journal of Emerging and Selected Topics in Power Electronics, 2014, vol. 2, no. 3, pp. 552-561. doi: 10.1109/JESTPE.2013.2297702.

10. Vural B., Boynuegri A.R., Nakir I., Erdinc O., Balikci A., Uzunoglu M., Gorgun H., Dusmez S. Fuel cell and ultracapacitor hybridization: A prototype test bench based analysis of different energy management strategies for vehicular applications. International Journal of Hydrogen Energy, 2010, vol. 35, no. 20, pp. 11161-11171. doi: 10.1016/j.ijhydene.2010.07.063.

11. Gao W. Performance comparison of a fuel cell-battery hybrid powertrain and a fuel cell-ultracapacitor hybrid powertrain. IEEE Transactions on Vehicular Technology, 2005, vol. 54, no. 3, pp. 846-855. doi: 10.1109/TVT.2005.847229.

12. Reddy N.P., Pasdeloup D., Zadeh M.K., Skjetne R. An intelligent power and energy management system for fuel cell/battery hybrid electric vehicle using reinforcement learning. IEEE Transportation Electrification Conference, 2019, pp. 1-6. doi: 10.1109/ITEC.2019.8790451.

13. Yu S., Fernando T., Chau T.K., Iu H. H.-C. Voltage control strategies for solid oxide fuel cell energy system connected to complex power grids using dynamic state estimation and STATCOM. IEEE Transactions on Power Systems, 2017, vol. 32, no. 4, pp. 3136-3145. doi: 10.1109/TPWRS.2016.2615075. 
14. Ehsani M. Modern electric, hybrid electric, and fuel cell vehicles: fundamentals, theory, and design. Power electronics and applications series. Boca Raton, CRC Press, 2005.

15. Saïsset R. Contribution à l'étude systémique de dispositifs énergétiques à composants électrochimiques. Formalisme Bond Graph appliqué aux piles à combustible, accumulateurs LithiumIon, Véhicule Solaire (PhD), 2004.

16. Fuel Cell Technologies Program: Glossary. Department of Energy efficiency and Renewable Energy Fuel Cell Technologies Program, 2011.

17. Motapon S.N., Tremblay O., Dessaint L.A. A generic fuel cell model for the simulation of fuel cell vehicles. IEEE Vehicle Power and Propulsion Conference, 2009, pp. 1722-1729. doi: 10.1109/VPPC.2009.5289692.

18. Price A. Electrical energy storage - a review of technology options. Proceedings of the Institution of Civil Engineers - Civil Engineering, 2005, vol. 158, no. 6, pp. 52-58. doi: 10.1680/cien.2005.158.6.52.

19. Tangsiripaisan M.P. Modeling of fuel cell vehicle based on physical model of different components in MATLAB/Simulink. 2007.

20. Kawachi S., Baba J., Kikuchi T., Shimoda E., Numata S., Masada E., Nitta T. Energy capacity reduction of energy storage system in microgrid stabilized by cascade control system. 13th European Conference on Power Electronics and Applications, 2009, pp. 1-10.

21. Tremblay O., Dessaint L., Dekkiche A. A generic battery model for the dynamic simulation of hybrid electric vehicles. IEEE Vehicle Power and Propulsion Conference, 2007, pp. 284289. doi: 10.1109/VPPC.2007.4544139.

22. Shepherd C.M. Design of primary and secondary cells - Part 2. An equation describing battery discharge. Journal of Electrochemical Society, 1965, Vol. 112, pp. 657-664.
23. Tremblay O., Dessaint L.-A. Experimental validation of a battery dynamic model for EV applications. World Electric Vehicle Journal, 2009, vol. 3, no. 2, pp. 289-298. doi: $10.3390 /$ wevj3020289.

24. Njoya Motapon S., Dessaint L.-A., Al-Haddad K. A comparative study of energy management schemes for a fuelcell hybrid emergency power system of more-electric aircraft. IEEE Transactions on Industrial Electronics, 2014, vol. 61, no. 3, pp. 1320-1334. doi: 10.1109/TIE.2013.2257152.

25. Available at: http://www.brusa.biz/en/products/dcdcconverter/hvhv-800-v/bdc546.html (accessed 12 March 2020).

Received 26.04.2020

Accepted 03.10.2020

Published 24.12.2020

Billel Bourouis ${ }^{1}$, PhD Student

Hind Djeghloud ${ }^{2}$, Lecturer

Hocine Benalla ${ }^{1}$, Professor

${ }^{1}$ Laboratory of Electrotechnics of Constantine (LEC),

Mentouri Brothers University, Constantine 1,

Campus Ahmed Hamani Zerzara,

Route d'Ain el Bey, Constantine, 25000, Algeria.

${ }^{2}$ Laboratory of Electrical Engineering of Constantine (LGEC), Mentouri Brothers University, Constantine 1,

Campus Ahmed Hamani Zerzara,

Route d'Ain el Bey, Constantine, 25000, Algeria.

e-mail: billelbourouis1@outlook.com, hind.djeghloud@umc.edu.dz,

hocine.benalla@umc.edu.dz

How to cite this article:

Bourouis B., Djeghloud H., Benalla H. An innovative algorithm for a hybrid FC/battery system energy management. Electrical engineering \& electromechanics, 2020, no. 6, pp. 35-44. doi: 10.20998/2074-272X.2020.6.06. 